\title{
CRY1 Gene
}

National Cancer Institute

\section{Source}

National Cancer Institute. CRY1 Gene. NCI Thesaurus. Code C101343.

This gene plays a role in circadian rhythm. 